Nloman 2019, 37(2), 25-33

Revista de Psicologia, Ciències de l'Eduació i de l'Esport

ISSN: 1138-3194

CFacultat de Psicologia, Ciències de l'Educació i de l'Esport Blanquerna

Universitat Ramon Llull

\title{
Design and Validation of a Questionnaire In Order to Assess the Adaptation of Educational Practices to the Flipped Learning Model
}

\author{
María Teresa Sánchez-Compaña \& Cristina Sánchez-Cruzado \\ University of Málaga
}

Received: 2019-6-26

Accepted: 2019-9-25

Design and Validation of a Questionnaire In Order to Assess the Adaptation of Educational Practices to the Flipped Learning Model

Summary. This paper details the design and validation process of a questionnaire that allows teachers to assess themselves in how they apply the flipped learning model in their professional teaching practice. More specifically, the tool will assess the degree to which a given teacher's practices are in keeping with general standards established for this teaching model. In the design phase, a previously existing questionnaire on the same topic was used, and a thorough review of its structure and items was conducted, taking as a reference the general standards established by international experts in the design and application of the model. The validation phase consisted of two procedures. First, 12 teachers and professors who use flipped learning lent their expert judgement, and their answers and suggestions were analysed and incorporated into the design of an initial pilot version of the questionnaire. The second phase consisted of validation and reliability testing through the analysis of the answers offered by the 76 teachers who responded to the questionnaire. After this process, the questionnaire can be regarded as scientifically valid and suitable for its purpose.

Keywords: flipped learning; ICT competences; teaching innovation; validation of questionnaires

Diseño y validación de un cuestionario para evaluar la adecuación de prácticas educativas bajo el modelo flipped learning

Resumen. En el presente artículo se exponen los pasos seguidos para el diseño y la validación de un cuestionario que permita evaluar al profesorado que emplea en su práctica profesional docente el modelo Flipped Learning. Se pretende valorar cuánto se adecúan dichas prácticas a los estándares generales establecidos para dicho modelo. Para la fase del diseño, se ha partido de un cuestionario previo, realizando una profunda revisión del mismo, y teniendo como referencia los estándares generales determinados por las personas expertas en la creación y aplicación del modelo Flipped Learning a nivel internacional. La fase de validación se ha realizado mediante dos procedimientos. Por una parte, se ha llevado a cabo una consulta a 12 expertos, cuyas respuestas y sugerencias fueron analizadas y consideradas para el diseño de un cuestionario piloto, con el que se ha abordado la segunda fase, en la que se analiza si el cuestionario cumple unos criterios mínimos de validez y fiabilidad, a través del análisis de las respuestas ofrecidas por las 76 personas que participaron de la experiencia piloto. Tras este proceso, se considera que el cuestionario diseñado es válido científicamente además de ser adecuado para su propósito.

Palabras clave: flipped learning; competencias TIC; innovación docente; validación de cuestionarios 


\section{Introduction}

Students should be provided with an educational environment that can truly meet their needs, a school setting that adapts to each individual. This is the case because there are real differences in the ways in which different students approach and complete educational tasks (Ramírez, Ruiz \& Albert, 1996).

A number of authors have argued that the use of teaching methodologies such as the "flipped learning" model can lead to strongly positive results. They have pointed to outcomes such as decreases in the dropout rate and improvements in grade averages, as well as to students' belief that flexible teaching methods foster independent learning, autonomy and cooperation (Mason, Shuman \& Cook, 2013; Touchton, 2015; Sánchez \& Arrufat, 2016).

These emerging educational needs bring with them new responsibilities for teachers. As Gairín, Feixas, Guillamón and Vilamitjana observed (2004):

In this new context, the task of university professors is no longer merely to transmit knowledge, as they devote a growing percentage of their teaching activity to guiding individual students, mainly helping them on their academic path, but also offering professional and personal guidance. A student's education is not limited to the classroom, but rather encompasses a whole range of other synchronous and asynchronous curricular resources, including libraries, software programmes, websites, activities both inside and outside the classroom, etc. (Gairín et al., 2004, p.65).

Under these circumstances, flipped learning has come to be viewed as a methodological framework that makes it possible for teachers to meet the needs of all their students. The "flipped" approach turns the traditional classroom model on its head, as students are introduced to concepts before class, thus allowing teachers to devote class time to assisting and guiding each student as they apply the essential content of a course via active, practical, innovative tasks (Santiago \& Bergmann, 2018).

Flipped learning sometimes amounts to nothing more than asking students to read or prepare certain educational materials presented by the professor before a class session, so that class can be spent on more reflective, collaborative, participatory activities. However, with the support of Information and Communication Technologies (ICT) these methods can be truly effective, as students can be given access to enriched content, presented in an attractive format and accessible from anywhere and at any time (Davies, Dean \& Ball, 2013).

Most teachers have a good degree of mastery of technology, and they live their lives on both the digital and real-world planes (Tourón \& Santiago, 2015). Applying this kind of thinking to the classroom is the next logical evolutionary step, one that involves forging connections between formal and informal learning.

Under the flipped learning model, students absorb theoretical concepts at home, while in the classroom they complete activities and tasks that give rise problematic situations, which they work to overcome with the teacher's supervision (see table 1).

Touchton (2015) quotes Conklin's (2005) discussion of Bloom's (1956) taxonomy of levels of learning to suggest that "flipping" the classroom and using other pedagogical methods to support active learning can do more to foster the teaching and learning process than traditional methodology. According to Touchton, this is the case because under the inverted classroom method students work at home on easier tasks, those that are lower down on Bloom's revised pyramid. Meanwhile, the higher-order tasks are done in class with the support of the teacher and a student's classmates.

Bloom (1956) identified three dimensions of the taxonomy of learning objectives: the affective, psychomotor and cognitive domains. In the cognitive domain, he set out six categories, running the gamut from lower-order to higher-order thinking processes. This classification was later revised by Anderson and Krathwohl (2001) to reflect the active nature of the learning process. Table 2 shows the various categories of the cognitive domain. The bottom of the table features the terms associated with lower-order thinking, while the upper part displays the terms connected to higherorder thinking.

Active learning is defined as learning that occurs when the teacher abandons lecture-based classes. In these classes, the teacher usually assigns students to work in groups to answer questions or complete tasks designed to help them grasp concepts (Andrews, Leonard, Colgrove \& Kalinowski, 2011). These authors review a number of studies that have found active learning methods to be much more effective than traditional classes, and they highlight clear evidence that students learn more with active methods.

Table 1. The role of the teacher in a flipped classroom. Adapted from Tourón and Santiago (2015)

\begin{tabular}{lll}
\hline Time & Teacher in a traditional classroom & Flipped classroom \\
\hline Before class & Prepare a presentation or lecture. & Prepare a range of enriching activities. \\
\hline Start of class & Highlight what is most important or relevant. & $\begin{array}{l}\text { Teachers and should anticipate the areas that are likely to } \\
\text { be most difficult for students. }\end{array}$ \\
\hline During class & $\begin{array}{l}\text { Teach the lesson based on the materials prepared } \\
\text { beforehand. Attempt to cover all the material in the } \\
\text { curriculum. }\end{array}$ & $\begin{array}{l}\text { The teacher acts as a guide, serving the needs of a given } \\
\text { group. The teacher develops micro-lessons that delve } \\
\text { deeply into key points and more advanced levels or that } \\
\text { address difficulties. }\end{array}$ \\
\hline During class & $\begin{array}{l}\text { Correct/supervise/grade the activities and exercises } \\
\text { completed at home. }\end{array}$ & $\begin{array}{l}\text { Offer students additional explanations and resources, and } \\
\text { supervise their work. }\end{array}$ \\
\hline Office hours/individualised sessions & Frequently, repeat parts of classroom lectures. & Continue guiding students toward deeper learning. \\
\hline
\end{tabular}


Table 2. The cognitive domain of Bloom's taxonomy. Adapted from Macías (2017)

\begin{tabular}{ll}
\hline Original categories & Revised categories \\
\hline Evaluation & Create \\
\hline Synthesis & Evaluate \\
\hline Analysis & Analyse \\
\hline Application & Apply \\
\hline Understanding & Understand \\
\hline Knowledge & Remember \\
\hline
\end{tabular}

Abeysekera and Dawson (2015) have pinpointed a number of key elements that should be included in a flipped learning approach. First, students should have the opportunity to access course content prior to class, for example by viewing or listening to recorded lessons. There should be an incentive for students to prepare before attending class, for example quizzes or contests at the start of each session. There should be a mechanism such as a graded quiz to ensure that students have learned the content. Finally, classroom sessions should focus on activities demanding a higher cognitive level and promoting active learning, including practices such as peer learning and problem solving.

All of this represents a starting point, some of the basic ideas involved in undertaking a classroom strategy based on flipped learning. The ideas can take as many different forms as there are teachers and groups of students. In any case, the teacher should maintain control of the classroom and serve as a guide and a source of support, redirecting students' learning when necessary and harnessing the method's potential to delve more deeply into the subject matter than would be possible in a traditional classroom. The teacher's role in this method is indispensable. If students do not perceive the importance and value of the teacher's presence, they may come to think that flipped learning consists merely of watching videos online, and they may meet in groups outside class to discuss the materials, thus denying the teacher the chance to offer them any added educational value (Kuiper, Carver, Posner, \& Everson, 2015; Touchton 2015).

In an effort to produce an unambiguous definition of the flipped learning model, a project is under way with the aim of creating a basic framework of reference, one that will provide teachers who use this educational method with access to information on the latest best practices from around the world. To achieve this, an international delegation of flipped learning professionals from over 49 countries came together to draft a series of globally applicable standards and a categorisation of the model. Leading the effort were six international experts: Dr. Eric Mazur (Harvard University), Jon Bergmann (Flipped Learning Global Initiative), Dr. Caroline Fell Kurban (MEF University), Dr. Raúl Santiago (Universidad de La Rioja), Robyn Brinks Lockwood (Stanford University) and Dr. Gwo-Jen Hwang (National Taiwan University of Science and Technology).

There is a need to determine whether and to what degree the standards this group issued are suitable and effective for assessing educational practices carried out under the banner of flipped learning. It would be useful, then, to produce a questionnaire capable of gathering precise and relevant data on these standards.

\section{Objective}

The main aim of this research is to design and validate a questionnaire to assess professors who employ the flipped learning model as part of their teaching practices. The goal is to create a reliable instrument that can determine whether a given teacher's approach meets the general criteria that have been established for the flipped learning model.

The study's specific objectives are:

- To determine whether the core standards agreed upon by experts in the flipped learning model can be used to evaluate the educational activities being carried out according to this perspective,

- To describe the structure and design of a tool to allow teachers to perform self-assessments to determine whether their flipped learning educational practices are suitable,

- To analyse the state of the art when it comes to the flipped classroom.

There was some consideration of the possibility of using an existing questionnaire, but in the end the researchers opted to design a new one, based on an earlier model, in the hope that it would be optimally suited to assessing these teaching practices. The questionnaire was adapted, updated and improved, taking into account the general standards that had been established for the flipped learning model.

This article details the design and validation phases of the instrument. A first draft of the new questionnaire took into account the established standards. Later, experts were consulted in the drafting of a new version of the questionnaire, which was then used in a pilot study. The results obtained using the questionnaire were then analysed in order to confirm and assess the reliability and validity of the process as a whole.

\section{Method}

This section is split into two subsections. The first contains a detailed description of the design phase of the questionnaire, and the second sets out the validation process.

\section{Questionnaire Design Phase}

The study began by an examination of an existing questionnaire on the topic that had yet to be validated. This was followed by a review of the background literature. The research team that came together for this study boasted the invaluable presence of Jon Bergmann (Flipped Learning Global Initiative) and Dr. Raúl Santiago (Universidad de La Rioja). The aim was to design and validate a questionnaire that would make it possible to assess the professional practices of teachers using the flipped learning model. 
In the initial phase of the efforts to create an instrument to serve this purpose, the specific objectives of the study were determined. After the objectives had been established, all the necessary information on the subject of study was gathered (Fox, 1987). Some of this information was gleaned from a highly detailed analysis of both the Spanish (The Academy of Active Learning Arts and Sciences LLC, 2019a) and English (The Academy of Active Learning Arts and Sciences LLC, 2019b) versions of the flipped learning standards, which helped shed light on some of the core characteristics of flipped learning.

Based on this initial analysis and after a joint process of deliberation, it was decided to incorporate into the design of the questionnaire the 11 domains into which the flipped learning standards are classified: "Understanding flipped learning", "Planning for flipped learning", "Assessment", "Learning spaces", "Individual space mastery", "Student involvement", "Communication and culture", "Professional development", "Evidence and research" and "IT infrastructure".

The questionnaire was then checked against these 11 domains and the specific standards identified within each dimension, resulting in the drafting of a more definitive series of questions. This is the most sensitive part of the creation of a questionnaire, and it is especially important in research using surveys (Cohen \& Manion, 1990). In this case, this phase of the project was especially complex. The members of the research team collaborated to identify items that would ensure that the 11 domains of the core flipped classroom standards would be reflected in the final instrument.

In this initial version of the instrument, the items are in English. The aim is to create a questionnaire that will be used internationally and translated into a number of languages. The questions were drafted with the guidelines established by Alaminos and Castejón (2006) in mind. These authors suggest that

- each item should address only a single issue

- questions should be clear, simple and concise

- repeated questions or insufficiently exclusive questions should be avoided

- the words used should be understood in the same way by all potential respondents

- the vocabulary used should be appropriate and accessible to all members of the population studied

- biased questions should be avoided.

Ultimately, it was decided that the study should begin with seven general questions designed to help characterise the respondents: "Gender", "What is your age? (choose a range)", "How long have you been teaching? (choose a range)", "What type of school do you work in?", "Educational level where you teach in", "What subjects-area do you teach?" and, finally, "How long have you used flipped learning?".

The remaining 45 items consist of sentences or statements that express the core flipped classroom standards for each of the 11 dimensions. Some of the items are phrased positively and others negatively. They are answered on a four-point Likert scale. According to various authors (Alaminos \& Castejon, 2006; Albert, 2007), this type of scale leads to the coding of answers based on an ordinal level that forces interviewees to take a favourable or unfavourable position with regard to each item. More specifically, respondents were able to choose among four possible answers to each item: $0=$ Strongly agree; $1=$ Agree; $2=$ Disagree; $3=$ Strongly disagree. This phase of the questionnaire's design concluded with the sequencing of the questions, taking into account the standard that each question referred to and the dimension to which each of these standards belonged.

Thus, the questionnaire is made up of a total of 52 items, divided into two different sections. The first section consists of seven items aimed at gathering data to characterise the population, while the second section is aimed at assessing the degree to which the respondents' professional flipped learning practices are in accordance with the international standards established for this educational model. The second section itself is divided into 11 subsections, each of them corresponding to one of the 11 domains of the flipped learning standards.

The first of these domains, "Understanding flipped learning", encompasses four standards (items 8 to 11):

8. "I am able to define what Flipped Learning is."

9. "I understand that Flipped Learning is a strategy that enables active learning."

10. "I can distinguish between Flipped Learning and Blended Learning."

11. "I understand how the role of educator goes from "transmitter" to "facilitator."

The second domain, called "Planning for flipped learning" covers five standards, (represented by items 12 to 16$)$ :

12. "I apply the principles of pedagogy and andragogy in the design of my contents and activities for flipped learning."

13. "I apply Bloom's taxonomy in the design of my contents and activities for flipped learning."

14. "I plan activities for both the individual space and the group space."

15. "I am able to define learning objectives and design activities to achieve them."

16. "I rethink the design of flipped learning with large groups of students."

The next domain is "Assessment," and it covers five standards (items 17 to 21 ):

17. "I use formative assessment."

18. "I use a large part of class time to participate in structured micro-conversations with students."

19. "I use different types of questions according to the BLOOM taxonomy."

20. "I use rubrics or other assessment tools linked to learning outcomes as a means of evaluation."

21. "I propose evaluation systems that involve the creation of real life products or the use of real life skills by the student." 
The fourth domain is called "Learning spaces" «LEARNING SPACES», and is assessed using two items (items 22 and 23):

22. «I creatively modify the physical space of the classroom to encourage active learning»

23. «I give flexibility and autonomy to students in the use of physical space»

The fifth domain, "Individual space mastery", includes the largest number of items and covers nine different standards (items 24 to 32):

24. "I make sure that the pre-class materials imply an adequate workload based on age and that it contains the main idea."

25. "I make sure that the pre-class materials are designed according to the "low" levels of the BLOOM taxonomy (remember and understand)."

26. "I make sure that there is a clear connection between pre-class material and class activities."

27. "I strategically select the most appropriate tool for the creation of pre-class material."

28. "I teach my students to interact with a pre-class video to get the most out of it, for example, to take notes and prepare questions for class."

29. "I make sure that the pre-class material is meaningful and motivating for the student."

30. "I include questions in the pre-class material to reinforce the basic concepts."

31. "I take advantage of the data collected from the work of the students in the pre-class work."

32. "I take into account legal aspects regarding the right to privacy of my students according to the laws of each country."

The sixth domain is called "Group space mastery" and is assessed using seven items (items 33 to 39):

33. "I make sure that the class activities are designed according to the "high" levels of the BLOOM taxonomy, (application, analysis, evaluation and creation)."

34. "I give responsibilities to students during class time."

35. "I select the most appropriate active methodologies in the group space."

36. "I do not explain the learning content to students who have not done the pre-class work."

37. "I carry out reflection activities at the end or during the class work."

38. "I perform differentiation activities, adaptation to rhythms and learning styles in the group space."

39. "I use both digital and analogue tools for work in the group space."

The following domain, "Student involvement",

includes two standards (items 40 and 41):

40. "I keep in mind my students' feedback on pre-class work."

41. "I take into account the feedback of my students about the activities of the group space."

The eighth domain, "Communication and culture", consists of five standards. They are assessed via five items (items 42 to 46 ):

42. "I build positive relationships with my students."
43. "I help / I teach my students to understand and see the big ideas."

44. "I teach my students to learn according to the FLIP mode."

45. "I understand / identify the different cognitive needs of my students."

46. "I encourage my students to learn from mistakes." The ninth domain, "Professional development", is addressed by two items (items 47 and 48):

47. "I am aware of the latest findings about Flipped Learning and keep them in mind for my practice."

48. "I make sure to continuously develop my own skills and knowledge about Flipped Learning."

The next domain, "Evidence and research", consists of items measuring two standards (items 49 and 50):

49. "I collect information about my own results from my flipped class."

50. "I share my findings and results with other colleagues."

The final domain, "IT infrastructure", is covered by two items (items 51 and 52):

51. "I use the most appropriate technology for my students and their own devices."

52. "I select the technology that ensures the privacy and security of my students online."

When a participant has completed the questionnaire, a total score of between 1 and 100 is calculated, with 100 being the maximum possible score. This score reflects the degree to which the participant's teaching practice is in keeping with the flipped learning model, as well as offering a basis for comparison with other participants. It also guides participants toward areas with room for improvement and helps inform their approach to future professional training.

\section{Results}

\section{Questionnaire Validation Phase}

After the questionnaire had been drafted, the next objective was to confirm its validity, as this represented a new version of an original questionnaire that had yet to be validated. To this end, it was necessary to implement a methodologically suitable validation procedure. For the purposes of this study, the procedure used consisted of a consultation with experts. In the words of Ruiz (2002: 75), "The aim in validating the content of an instrument is to determine the degree to which the items are representative of the domain or universe of content of the property whose measurement is sought."

\section{Validity Analysis}

Twelve experts took part in the validation analysis of the content of the questionnaire. The experts were teachers from all educational levels with a median age of 44 . All of them had been applying flipped learning methodology for over four years, with the exception of one teacher who had only been using the techniques 
Table 3. Quantitative and qualitative expert assessments

\begin{tabular}{|c|c|c|}
\hline Expert & $\begin{array}{l}\text { Qualitative assessment } \\
\text { General comments on the questionnaire /Proposed changes }\end{array}$ & $\begin{array}{l}\text { Overall quantitative } \\
\text { assessment of the } \\
\text { questionnaires degree of } \\
\text { adaptation to the general } \\
\text { standards (from } 0 \text { to } 10 \text { ) }\end{array}$ \\
\hline E01 & $\begin{array}{l}\text { Items } 24 \text { to } 31 \text { refer to pre-class materials. Using individual space like on other occasions might help. } \\
\text { Item } 36 \text { is very blunt, and could refer to having activities aimed at helping students acquire this knowledge. The } \\
\text { question is hard for me to answer, saying that I don't explain it to them, but that instead they realise it. }\end{array}$ & 9 \\
\hline E02 & $\begin{array}{l}\text { I thought the questionnaire was very thorough, direct and clear. My contributions are: } \\
\text { Question } 17 \text { asks about assessment of training. Would it be possible to take into account the diagnosis of the } \\
\text { individual space as an analysis of the students' status of learning prior to the class? } \\
\text { Question } 20 \text { focuses on rubrics only as assessment instruments. Comparison lists or assessment scales could be } \\
\text { added, as they help a lot throughout formative assessment for self-assessment. Or perhaps you could mention } \\
\text { "different formative assessment tools" }\end{array}$ & 10 \\
\hline E03 & No suggestions for improvement & 10 \\
\hline E04 & $\begin{array}{l}\text { In Block 4, on planning with flipped learning, there is nothing about the coherence between the activities in the } \\
\text { individual space and those in the standard group space: Ensure that pre-class link directly to learning outcomes and } \\
\text { group space activities. } \\
\text { Block 5, Assessment, item 18. You could complete the question with a reference to the standard: Have a plan for } \\
\text { students who come to class having completed the pre-work but still don't fully grasp the concepts, something like } \\
\text {...to make sure everyone can reach the required level. It would be nice to have a question that considers the } \\
\text { different forms of assessment, standard: Design assessments where students have a choice in how they will present } \\
\text { their mastery of the concept. It is also important to count every class activity, so that also could be included here. }\end{array}$ & 9 \\
\hline E05 & No suggestions for improvement & 10 \\
\hline$\overline{\mathrm{E} 06}$ & $\begin{array}{l}\text { The following standard does not contribute any difference with respect to any other methodology. "Presents the } \\
\text { contents of the course logically and consistently." In the following standard, I would also include diagnostic } \\
\text { assessment. "Uses frequent, formative assessments." } \\
\text { With "Provides assessments with clear rubrics", I would include assessment bullseyes or checklists. } \\
\text { I don't think the term "communication media" is right in the item that reads "Establishes student-centred activities } \\
\text { that encourage students to summarise the contents of the communication media of the previous class". } \\
\text { I would change the phrasing of "Conduct research on activities in your class and share them with the global } \\
\text { community" }\end{array}$ & 10 \\
\hline E07 & $\begin{array}{l}\text { In question 51, which says "I use the most appropriate technology for my students and their own devices" it would } \\
\text { be good to make clearer what we mean by "the most appropriate technology", or to reformulate the question in } \\
\text { more specific terms. }\end{array}$ & 9 \\
\hline E08 & No suggestions for improvement & 9 \\
\hline E09 & No suggestions for improvement & 10 \\
\hline E10 & $\begin{array}{l}\text { If I have to point to a "flaw" or minor criticism, I would say that in question } 12 \text {, which says "I know and I apply the } \\
\text { principles of pedagogy and andragogy in the design of my content and activities for flipped learning", I think it would be } \\
\text { good to add "and/or" between "pedagogy" and "andragogy", as a teacher might be applying the principles of } \\
\text { pedagogy but not those of andragogy, or vice-versa. }\end{array}$ & 10 \\
\hline E11 & $\begin{array}{l}\text { Uses a range of active learning strategies in the group space, including project-based learning, problem-solving, } \\
\text { mastery, genius hour and peer instruction. } \\
\text { Includes activities that encourage students to create their own content. }\end{array}$ & 10 \\
\hline E12 & $\begin{array}{l}\text { Question } 10 \text { is very direct and might cause people to answer that they don't know because of a lack of explanation. } \\
\text { Question } 12 \text { might also cause confusion. } \\
\text { In general, I think the questionnaire does a very good job covering the key aspects of flipped learning. } \\
\text { In the block on technology (or maybe elsewhere) there could be another question about software, applications, etc. }\end{array}$ & 10 \\
\hline
\end{tabular}

for one year. They teach a wide range of subject matter, from science and maths to language, social science and the arts. Nine of the experts were of Spanish nationality, while one was from Argentina, one from the UK and one from Peru.

Table 3 displays all the experts' contributions and numerical scores.

The numerical scores assigned by the experts to the questionnaire are 9 and 10, with a mean of 9.66 out of 10. In other words, the results were quite positive.

As a result of this validation process, a series of modifications were made to the items on the questionnaire to reflect the experts' contributions and suggestions. However, the overall structure of the questionnaire remained unchanged. The instrument remained structured as a series of eleven domains, each with its own items asking participants to respond to statements corresponding to the standards.

\section{Reliability Analysis}

The questionnaire was administered using the online platform Surveymonkey, and participants accessed it via a link (Santiago, Bergmann, Sánchez-Cruzado \& Sánchez-Compaña, 2019). See figure 1.
The questionnaire was administered to a pilot sample in order to test its reliability. According to Nisbet and Entwistle (1980), pilot testing is an indispensable phase of the development of any instrument. Gaitán and Piñuel (1998) recommend using a pilot sample of between 30 and 100. In this study, the sample was made up of 76 teachers. The time needed to complete the questionnaire ranged from 10 to 15 minutes.

Cronbach's Alpha was used to calculate the questionnaire's degree of reliability. To this end, the software programme IBM Statistical Package for the Social Sciences was used. This software is often used by social science and market researchers. The coefficient establishes the internal consistency among a series of items by calculating the degree of covariance among them (Celina \& Campo, 2005). The closer Cronbach's Alpha comes to a value of 1 , the greater the internal consistency of the items analysed (Goerge \& Mallery, 2002; Gliem \& Gliem, 2003). The figure obtained for this study was 0.975 , indicating an almost excellent degree of internal consistency.

The pilot questionnaire was completed by 76 teachers of a range of nationalities. The choice was made to use incidental or accidental sampling, with participants 


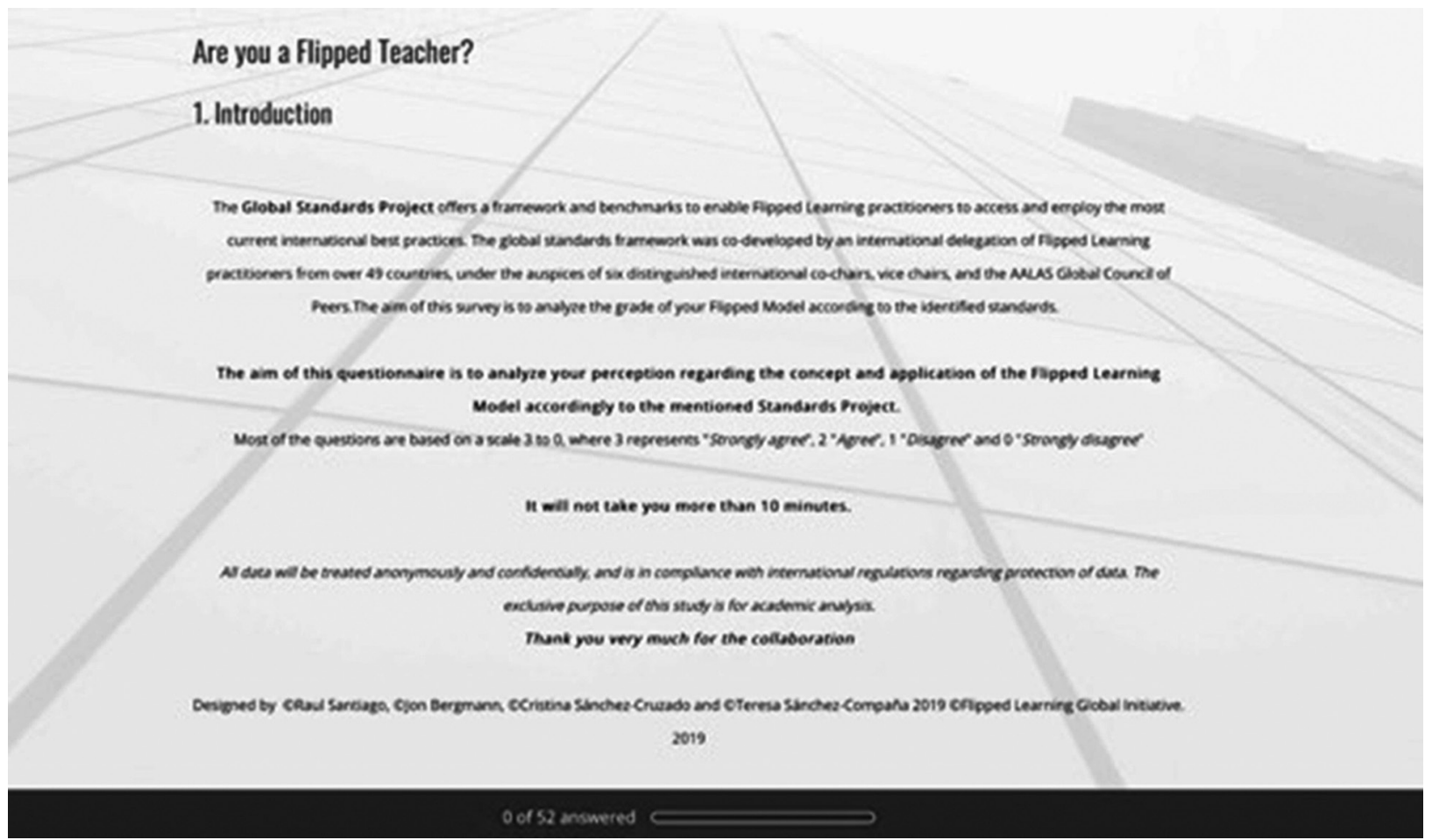

Figure 1. Screenshot of the first page of the questionnaire (Santiago, Bergmann, Sánchez-Compaña \& Sánchez-Cruzado, 2019).

selected due to ease of access (Pereda, 1986). Despite the type of sample used, the researchers believe that the information gathered makes it possible to determine the degree of reliability of the instrument, whose goal is to assess the degree to which the educational practices of teachers using the flipped learning model fit with the standards that characterise this model. It is believed that the information collected in this pilot study will provide consistent data on teachers' perception of their use of the flipped learning model. The participants in this pilot study were informed as to objectives of the study and freely and explicitly volunteered to take part in it.

After the data had been exhaustively filtered and incomplete questionnaires, atypical values and unclear answers had been eliminated, the study was left with 61 completed surveys, out of the 76 original participants, a response rate of $80 \%$. Of these participants, 27 (or $44.3 \%$ ) were women, and 34 (or 55.7\%) were men. Only $1.6 \%$ of the individuals in the sample were 25 years of age or younger, while $14.7 \%$ were between 26 and 35 years old, $27.8 \%$ were between 36 and $45,39.3 \%$ were between 46 and 55 , and $16.6 \%$ were 56 years of age or older. The mean age of the group was 45.8 , and the mode and median of the participants' ages were between 46 and 55, with coefficient of variation of .2143 .

In terms of the variable of "years of teaching experience," the answers were grouped into five ranges: teachers with under three years of teaching experience ( $9.8 \%$ of the sample), those with between three and five years of experience (4.9\%), from six to ten years (13.11\%), from 11 to 20 years (39.34\%) and 21 years or more $(32.85 \%)$.
The mean number of years worked is 15.73 , and the mode and median were between 11 and 20 years of experience, with a coefficient of variation of 0.49 .

There were three possible options for "Type of school": "public" (chosen by 22 people, or $36.1 \%$ of the sample), "private-subsidised" (chosen by 9 people, or $14.8 \%$ of the sample), and private (chosen by 30 people, or $49.2 \%)$.

In terms of the "Education level taught," two (3.3\%) of the respondents teach "Early childhood education," seven (11.5\%) are "Primary education" teachers, 17 (27.9\%) teach in "High school," and 24 are "University" professors. Finally, one teacher (1.6\%) chose "other" for this question.

With regard to the "Subject taught" by each of the participants, two (3.3\%) reported teaching "Arts or music," $13(21.3 \%)$ teach courses in the area of "Language," 20 (32.8\%) reported teaching subjects connected to "Science and Mathematics," 12 (19.7\%) are "Social Science" teachers, and a single participant (1.6\%) reported teaching "Physical Education." Finally 13 (21.3\%) of the respondents chose "Others" for this item.

\section{Discussion}

In broad terms, the main objective of this study has been met. The questionnaire allowing teachers using the flipped learning model to assess their educational practices has been successfully designed and validated. Specifically, the instrument is able to assess the degree to which a given teacher's practices fit with the general standards established for the flipped learning model. The process to assess the validity and reliabil- 
ity of this questionnaire has shown that the instrument can be used to assess whether a teacher is really implementing flipped learning correctly in his or her class.

Meanwhile, with regard to the specific objectives, it seems clear that the standard principles agreed upon by flipped learning experts are suitable tools for evaluating the degree to which educational practices are implementing this model in a suitable way. This would indicate that the standards were well chosen.

The structure and organization of the questionnaire provide teachers with a self-assessment tool to determine the extent to which their flipped learning practices meet the standards for this model. Meanwhile, a thorough statistical analysis of the data obtained via the questionnaire could shed light on the current status of the flipped classroom model. The questionnaire also could serve as a good foundation for the planning of teacher training, highlighting the most common difficulties and areas in need of improvement.

The flipped learning model has established a track record as a methodology that fulfills the need for the kind of teaching and learning process that fosters cooperation and collaboration, the kind that results in more active and motivated students who are more engaged with their own learning process. It is a method that can adapt to meet the needs of students who learn at a range of different paces, and it can be used in the kind of experimental classes propel students toward greater independence and autonomous learning (Bergmann \& Sams, 2012; Mason, Shuman, \& Cook, 2013; Tourón \& Santiago, 2015). The great number of educators seeking to implement this teaching model means that there is a corresponding need for ways to assess whether certain practices truly meet the standards for flipped learning and embody its defining characteristics.

This questionnaire, designed with the help of international experts and proponents of the flipped learning model, represents a remarkable step toward the creation of the ideal instrument that is so sorely needed.

\section{Acknowledgements}

This study is part of a larger project entitled "Criteria and assessment instruments for teaching and learning units" (PPIT.UMA.B1.2017/16), financed by the University of Malaga for the academic years 2017-2019. It is also part of a research project with reference number PGC2018-094114-A-I00, financed by MINECO/MICIU.

\section{Author's statement}

The author reports no conflicts of interest.

\section{References}

Abeysekera, L. \& Dawson, P. (2015). Motivation and cognitive load in the flipped classroom: definition, rationale and a call for research. Higher Education
Research \& Development, 34(1), 1-14. https://doi.org/ 10.1080/07294360.2014.934336.

Alaminos, A. \& Castejón, J. L. (2006). Elaboración, análisis e interpretación de encuestas, cuestionarios y escalas de opinión. Alcoy: Marfil.

Albert, M. J. (2007). La investigación educativa. Claves teóricas. Madrid: McGraw Hill.

Anderson, L. W. \& Krathwohl, D. R. (2001). A taxonomy for learning, teaching, and assessing: A revision of Bloom's taxonomy of educational objectives. New York: Allyn and Bacon.

Andrews, T. M., Leonard, M. J., Colgrove, C. A. \& Kalinowski, S. T. (2011). Active Learning Not Associated with Student Learning in a Random Sample of College Biology Courses. CBE-Life Sciences Education, 10(4), 394-405. https://doi.org/10.1187/cbe.11-070061.

Bloom, B.S. (Ed.), Engelhart, M.D., Furst, E.J., Hill,W.H. \& Krathwohl, D.R. (1956). Taxonomy of educational objectives: The classification of educational goals. Handbook 1: Cognitive domain. New York: David McKay Company.

Bergmann, J. \& Sams, A. (2012). Flip Your Classroom: Reach Every Student in Every Class Every Day. Eugene, US: ISTE. Recuperado a partir de https://goo.gl/KP5dPL.

Bergmann, J. \& Santiago, R. (2018). ¿Eres realmente un docente flipped? https://es.surveymonkey.com/r/docente_flipped 2018

Celina, H. \& Campo, A. (2005). Aproximación al uso del coeficiente Alfa de Cronbach. Revista Colombiana de Psiquiatría, 34(4), 572-580.

Cohen, L. \& Manion, L. (1990). Métodos de investigación educativa. Madrid: La Muralla.

Conklin, J. (2005). [Review of Review of A Taxonomy for Learning, Teaching, and Assessing: A Revision of Bloom's Taxonomy of Educational Objectives Complete Edition, por L. W. Anderson, D. Krathwohl, P. Airasian, K. A. Cruikshank, R. E. Mayer, P. Pintrich, M. C. Wittrock]. Educational Horizons, 83(3), 154-15

Davies, R. S., Dean, D. L. \& Ball, N. (2013). Flipping the classroom and instructional technology integration in a college-level information systems spreadsheet course. Educational Technology Research and Development, 61(4), 563-580. https://doi.org/10.1007/s11423013-9305-6

Fox, D. J. (1987). El proceso de investigación en educación. Pamplona: EUNSA.

Gairín Sallán, J. G., Feixas, M., Guillamón, C. \& Vilamitjana, D. Q. (2004). La tutoría académica en el escenario europeo de la Educación Superior. Revista interuniversitaria de formación del profesorado 49(18), 61-78.

Gaitán, J. A. \& Piñuel, J. L. (1998). Técnicas de investigación en comunicación social. Elaboración y registro de datos. Madrid: Síntesis.

George, D. \& Mallery, P. (2002). SPSS for Windows Step by Step: A Simple Guide and Reference, 11.0 Update (4 edition). Boston: Allyn \& Bacon. 
Gliem, J. A. \& Gliem, R. R. (2003). Calculating, Interpreting, and Reporting Cronbach's Alpha Reliability Coefficient For Likert-Type Scales. Presentado en Midwest Research-to-Practice Conference in Adult, Continuing, and Community Education, Columbus, OH. Retrieved from https://bit.ly/2gCo4WY.

Kuiper, S. R., Carver, R. H., Posner, M. A. \& Everson, M. G. (2015). Four Perspectives on Flipping the Statistics Classroom: Changing Pedagogy to Enhance Student-Centered Learning. PRIMUS, 25(8), 655682. https://doi.org/10.1080/10511970.2015.1045 573

Macías, J. A. (2017). El papel del docente en un aula invertida universitaria. Un estudio de caso. (Trabajo fin de Máster, Universidad de Málaga). Retrieved from http://maciasgarcia.es/docs/Macias2017.pdf

Mason, G. S., Shuman, T. R. \& Cook, K. E. (2013). Comparing the Effectiveness of an Inverted Classroom to a Traditional Classroom in an Upper-Division Engineering Course. IEEE Transactions on Education, 56(4), 430-435. https://doi.org/10.1109/ TE.2013.2249066

Nisbet, J. D. \& Entwistle, N. J. (1980). Métodos de investigación educativa. Barcelona: Oikostau.

Pereda Marín, S. (1986). Psicología experimental. I, Metodología. Madrid: Pirámide.

Ramírez, F. C., Ruiz, M. J. \& Albert, M. E. (1996). Los estilos de aprendizaje y el rendimiento en Ciencias Sociales y en Ciencias de la Naturaleza en estudiantes de Secundaria. Anales de psicología, 12(2), 153166.
Ruiz, C. (2002). Instrumentos de investigación educativa: Procedimientos para su diseño y validación. Barquisimeto. CIDEG (Centro de Investigación y Desarrollo en Educación y Gerencia).

Sánchez, V. G. \& Arrufat, M. J. G. (2016). Modelo de análisis de metodologías didácticas semipresenciales en Educación Superior. Educación XX1, 19(1). https:// doi.org/10.5944/educxx1.15577.

Santiago, R. \& Bergmann, J. (2018). Aprender al revés: flipped classroom y metodologías activas en el aula. Barcelona: Planeta-Paidós.

Santiago, R., Bergmann, J., Sánchez-Cruzado, C. \& Sánchez-Compaña, M.T. (2019), Are you a flipped teacher?, https://es.surveymonkey.com/r/Beta16_04.

The Academy of Active Learning Arts and Sciences LLC (2019a). AALAS Estándares Generales. Retrieved from http://aalasinternational.org/aalas-estandares-generales/

The Academy of Active Learning Arts and Sciences LLC (2019b). AALAS General Standars. Retrieved from http://aalasinternational.org/aalas-general-standards/

Touchton, M. (2015). Flipping the Classroom and Student Performance in Advanced Statistics: Evidence from a Quasi-Experiment. Journal of Political Science Education, 11(1), 28-44. https://doi.org/10.1080/1 5512169.2014 .985105

Tourón, J. \& Santiago, R. (2015). El modelo Flipped Learning y el desarrollo del talento en la escuela. Revista de Educación, 368 (April-June), 196-231. https:// doi.org/10.4438/1988-592X-RE-2015-368-288 